Biol. Stud. 2020: 14(1); 23-32 • DOI: https://doi.org/10.30970/sbi.1401.608

www.http://publications.Inu.edu.ua/journals/index.php/biology

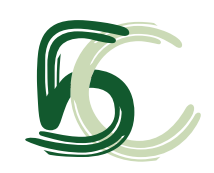

UDC: 615.26:615.281

\title{
ANTIMICROBIAL ACTIVITY OF NATURAL SOAPS TESTED BY BIOSCREEN METHODOLOGY
}

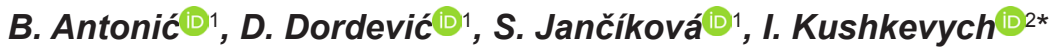 \\ ${ }^{1}$ Department of Plant Origin Foodstuffs Hygiene and Technology \\ Faculty of Veterinary Hygiene and Ecology \\ University of Veterinary and Pharmaceutical Sciences Brno, Czech Republic \\ ${ }^{2}$ Department of Experimental Biology, Faculty of Science \\ Masaryk University in Brno, Czech Republic \\ *Corresponding author: e-mail: kushkevych@mail.muni.cz
}

Antonić B., Dordević D., Jančíková S., Kushkevych I. Antimicrobial activity of natural soaps tested by Bioscreen methodology. Studia Biologica, 2020: 14(1); 23-32 • DOI: https://doi.org/10.30970/ sbi.1401.608

The aim of this study was to combine the utilization of waste frying oils within soap making process in order to make useful and environmentally friendly solutions and development of methods for determination of the antimicrobial effect of those created products. Soaps were made from edible oils which are fried in laboratory conditions. The antimicrobial activity of soaps was done against Staphylococcus aureus species as one of the representatives of the human skin microbiome. Two methods were applied: agar dilution method and the method including kinetics following on Bioscreen microbiology reader. In the first method, the number of CFU was followed on agar medium with and without different soap solutions after incubation for 24 hours at $30^{\circ} \mathrm{C}$. The result for $\mathrm{IC}_{50}$ (inhibition concentration for $50 \%$ of population) was $0.08 \mathrm{mg} / \mathrm{mL}$. Minimal inhibition concentration was detected at $0.41 \mathrm{mg} / \mathrm{mL}$ and minimal bactericidal concentration was observed at $>0.75 \mathrm{mg} / \mathrm{mL}$ for selected soap solution. Soap concentrations of $0.3 \mathrm{mg} / \mathrm{mL}$ of soaps (made from fresh and fried oil) were used for Bioscreen assessment with measurement on every hour during the 7 hours of incubation at $30^{\circ} \mathrm{C}$. 5 -second sequence of shaking of the microplate was applied before each measurement which was done at the wavelength of $610 \mathrm{~nm}$. The growth coefficients of the culture with soap solutions added and from the growth of culture only were compared. The growth of $S$. aureus subjected to soaps made from fresh and fried oils was inhibited $55.3 \%$ and

() 2020 Antonić Bojan. Published by the Ivan Franko National University of Lviv on behalf of Біологічні Студії / Studia Biologica. This is an Open Access article distributed under the terms of the Creative Commons Attribution License (http://www.budapestopenaccessinitiative.org and Creative Commons Attribution 4.0 License), which permits unrestricted reuse, distribution, and reproduction in any medium, provided the original work is properly cited.

ISSN 1996-4536 (print) • ISSN 2311-0783 (on-line) • Біологічні Студії / Studia Biologica • 2020 • Том 14/№1 • С. 23-32 
$69.7 \%$ respectively against the control during the first seven hours of incubation. From results obtained, it was concluded that there is a great potential of the Bioscreen as a method for further studies on antibacterial activity of soaps made from waste frying oils.

Keywords: skin microbiome, staphylococci, frying oils, soap, disinfection, new soap application, Bioscreen

\section{INTRODUCTION}

Soaps are the important industrial products for removal and neutralization of harmful and pathogenic microorganisms, which can be colonized on human skin forming biofilm [19]. The structure of such biofilm is complicated and depends on environmental factors and hygiene of each individual. Microbial skin biofilm helps bacteria to adapt to life on the skin surface and create mechanisms for survival of colonies. Creating of biofilms can also lead to creating virulence, pathogenesis and enhanced resistance to antibiotics [7].

The human skin is a habitat of different groups of microbial communities and their disbalance can endanger its protective role [10]. The main microbial genera, which can form biofilms in different parts of the human body are Staphylococcus, Micrococcus, Corynebacterium, Propionibacterium, Malassezi, Brevibacterium, Acinetobacter and Dermabacter. Among them, Staphylococcus aureus species was found to be the most common cause of human skin infections [17].

The commercially available hand soaps contain substances like triclosan, which have good antimicrobial properties but are also harmful to the human skin and microbiome [6]. It was also found that triclosan supports the growth of $S$. aureus in the nasal epithelium [21]. Various studies confirmed that there is no significant difference in the effect of antimicrobial soaps in comparison to plain soaps during the process of washing hands. While using antimicrobial soaps there is always a risk for increased resistance of certain microorganisms to the applied antibiotic [3]. Beside of fats and oils that are their constituents some antimicrobial agents like detergents are added in order to increase the power of the soap activity [18].

Frying oils are often used for temperature processing of various foods at high temperatures in the food industry, restaurants and households. About 17 million tons of waste frying oils are produced in the World annually and this production has an increasing trend [5]. The biggest environmental problem is its improper disposal, since it has as a consequence clogging of the drainage systems, harm to the wildlife and much more other [20]. In the process of wastewater treatment oil sticks to apparatuses, causes corrosion of the equipment and lowers the efficiency of wastewater treatment [13].

Today, there is a clear need to think about further use of some used product before its discharge. Reverse logistics systems play important roles in both environmental and economic aspects in the last 10-20 years [15]. The production of soaps is not harmful to nature since there are no by-products formed in its production. Also, it requires a minimal amount of energy used for the process of saponification [14]. In the process of saponification, we can also use waste frying oils and utilize it in a way which is harmless to the nature [8]. Nowadays, trends are going toward the direction of production of products of natural origin which does not include the addition of chemical agents. Since there is a great perspective for the production of soaps from waste frying oils, it is of crucial

ISSN 1996-4536 (print) • ISSN 2311-0783 (on-line) • Біологічні Студії / Studia Biologica • 2020 • Том 14/№1 • С. 23-32 
importance to investigate their antimicrobial and biological effects, including toxicity for microbial skin biofilm (main bacterial genera located on the skin) and eventual possible allergic reactions that these kind of products can cause. All these mentioned problems are still actual for finding perspective methods for utilization of waste frying oils, their application for safe soaps creation for human skin with inhibition effect for pathogenic microorganisms, but not for the commensal microbiome.

The Bioscreen microbiology reader is an instrument which works on the principle of measurement of optical density. While growing, microorganisms are changing the turbidity of the liquid media in which they are present. The instrument software can follow the kinetics and show the results as a change in optical density over time [12]. Readings are done for samples in wells of the microplate which can be thermostated. One microplate has 100 wells and the readings can be done on one or two plates.

The aim of this study was to compare the possibilities of the methods for determination of the antimicrobial activity of newly synthesized soaps made from used frying oils (agar dilution method on Petri dishes with an automated method using Bioscreen microbiology reader to follow the kinetics of the experiment setup).

\section{MATERIALS AND METHODS}

The samples of soap were synthesized from different types of oils at the Department of Plant Origin Foodstuffs Hygiene and Technology, Faculty of Veterinary Hygiene and Ecology, University of Veterinary and Pharmaceutical Sciences Brno, Czech Republic. The oils used for the experiments were olive oil „EL TORO" from producer Aceites Ybarra from Spain and rapeseed-palm oil (80:20) „FRITO MANKA“ from producer Fabio Product from the Czech Republic. The frying oils were prepared in laboratory conditions by consecutive heating and cooling of fresh samples of mentioned oils.

The soap for purpose of the experiment is made with potassium hydroxide using the cold method and the following recipe: $280 \mathrm{~g}$ of oil, $36.04 \mathrm{~g}$ and $34.00 \mathrm{~g}$ of sodium hydroxide $(\mathrm{NaOH})$ for the olive oil and rapeseed-palm oil soaps respectively and $106.40 \mathrm{~g}$ of distilled water. The $\mathrm{NaOH}$ and water were mixed in an ice bath and stirred until total dissolving of $\mathrm{NaOH}$. Then the oil was added and mixed until pudding-like consistency was reached. Once a visible trace appeared on the surface, the mixture was poured into a silicone mould and smoothed with a glass plate. After 24 hours, the soap was removed from the mould and transferred to a filter paper for maturing.

Staphylococcus aureus SA812 was used in this study. This bacterial strain was kept in Czech Collection of Microorganisms (CCM) at the Department of Experimental Biology, Faculty of Science at Masaryk University in Brno, Czech Republic. The culture of $S$. aureus SA812 was diluted to $10 \%$ solution in nutrient broth, HiMedia, India (peptone $5 \mathrm{~g}$, sodium chloride $5 \mathrm{~g}$, beef extract $1.5 \mathrm{~g}$, yeast extract $1.5 \mathrm{~g}$ ) and incubated for 24 hours at $30{ }^{\circ} \mathrm{C}$, after that, it was used for experiments.

The antimicrobial activity of the samples was done using the agar dilution method (Fig. 1) and determination of minimal inhibition concentration (MIC) [9].

The growth of Staphylococcus was followed on nutrient agar medium incubated at $30{ }^{\circ} \mathrm{C}$ on Petri dishes. Different concentrations of soap solution in quantity of $1 \mathrm{~mL}$ were added to the $19 \mathrm{~mL}$ of molten and tempered agar, mixed and then poured to the Petri dishes. Everything was done in triplicate together with control (culture incubated on Nutrient agar dishes only). Inhibition was calculated as the percentage of reduction of

ISSN 1996-4536 (print) • ISSN 2311-0783 (on-line) • Біологічні Студії / Studia Biologica • 2020 • Том 14/№1 • С. 23-32 
colonies on Petri dishes with added soap against the control. The results are presented as $\mathrm{IC}_{50}$ (inhibition concentration for $50 \%$ of the bacterial population), $\mathrm{IC}_{90}$ (inhibition concentration for $90 \%$ of the bacterial population which is also called MIC - minimal inhibition concentration), and MBC - minimal bactericidal concentration, above which there is no growth of bacterial colonies.
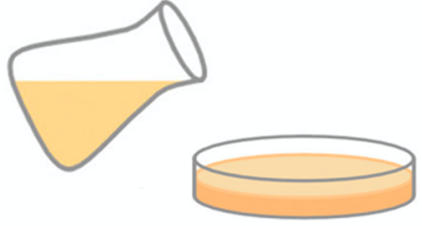

Tempered melted nutrient agar with addition of soap solution

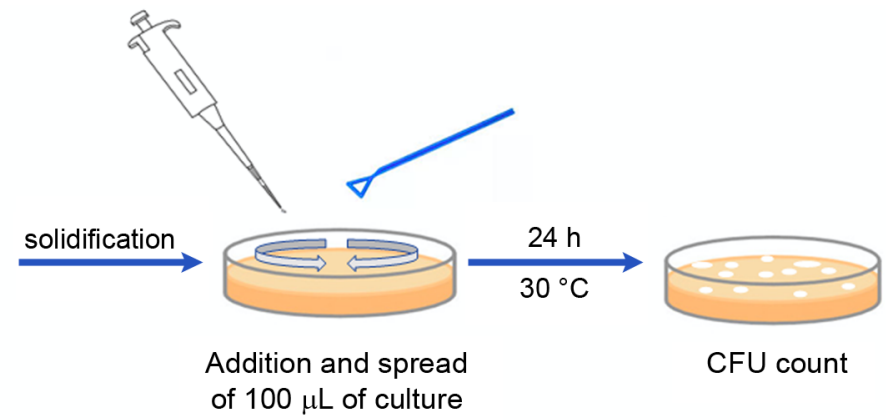

Fig. 1. Process flow in agar dilution method for determination of MIC

For the purpose of the experiment on Bioscreen, total volumes of $300 \mu \mathrm{L}$ of the sample were used (Fig. 2). For positive control, $30 \mu \mathrm{L}$ of culture was added to $270 \mu \mathrm{L}$ of nutrient broth and for negative control $300 \mu \mathrm{L}$ of Nutrient broth was used.
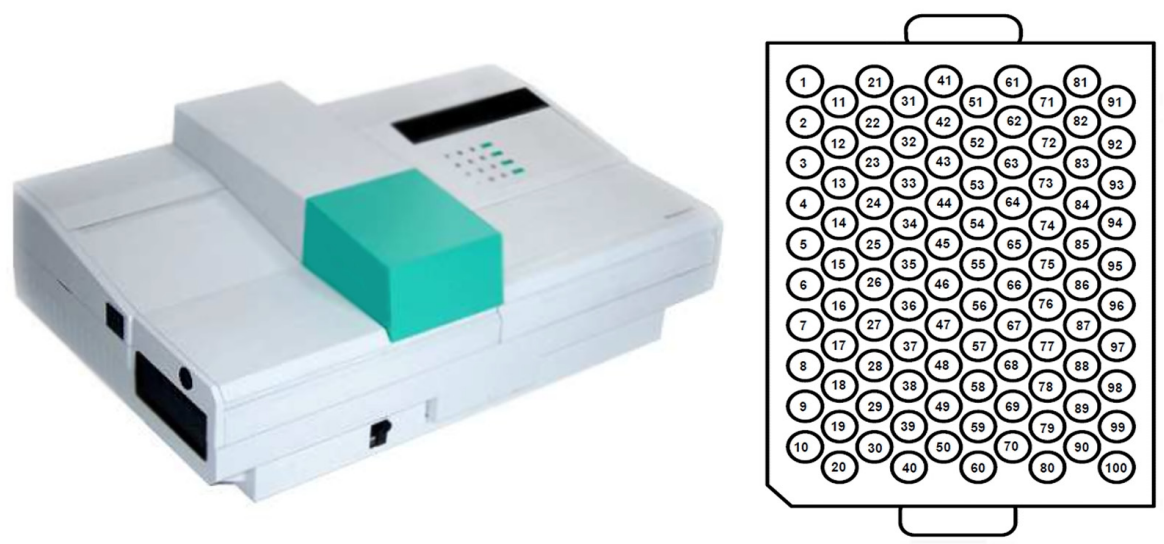

Fig. 2. Bioscreen microbiology reader on the left and honeycomb microplate on the right [4]

The testing sample contained $243 \mu \mathrm{L}$ of nutrient broth, $27 \mu \mathrm{L}$ of different soap concentrations and $30 \mu \mathrm{L}$ of culture suspension. Soap controls contained $273 \mu \mathrm{L}$ of nutrient broth and $27 \mu \mathrm{L}$ of soap solutions were used as a blank for testing samples. The screening was done during 7 hours, with measurement on each hour, and shaking of microplates for 5 seconds before each measurement. Measurement of optical density in the wells was done at a wavelength of $610 \mathrm{~nm}$. Each Bioscreen well was done in triplicate. The plots were built by software package Origin7.0 (Northampton, USA).

ISSN 1996-4536 (print) • ISSN 2311-0783 (on-line) • Біологічні Студії / Studia Biologica • 2020 • Том 14/№1 • С. 23-32 


\section{RESULTS AND DISCUSSION}

Results obtained in agar dilution method are presented in Fig. 3. From the graph $I_{50}$ and $I C_{90}$ values can be read. The $I_{50}$ value of the tested soap was $0.08 \mathrm{mg} / \mathrm{mL}$ while the MIC was detected at $0.41 \mathrm{mg} / \mathrm{mL}$. Values above $0.75 \mathrm{mg} / \mathrm{mL}$ were found to be totally bactericidal (MBC) with no visible growth of colonies of $S$. aureus. When comparing these results to the other similar studies, the results obtained for our soap were evidently better than the ones from the study of soap activity which contained hexane extract of leaves of Morinda morindoide. The values obtained there for $\mathrm{IC}_{50}$ and $\mathrm{MIC}$ were $2.64 \mathrm{mg} / \mathrm{mL}$ and $31.25 \mathrm{mg} / \mathrm{mL}$ respectively against $S$. aureus by using agar dilution method [1]. The study which was using disk diffusion method for the determination of the antibacterial activity of medicated soap "Crusader" also had much higher values for MIC and MBC on S. aureus then in this study and these were: $62.5 \mathrm{mg} / \mathrm{mL}$ and $125 \mathrm{mg} / \mathrm{mL}$ respectively [16].

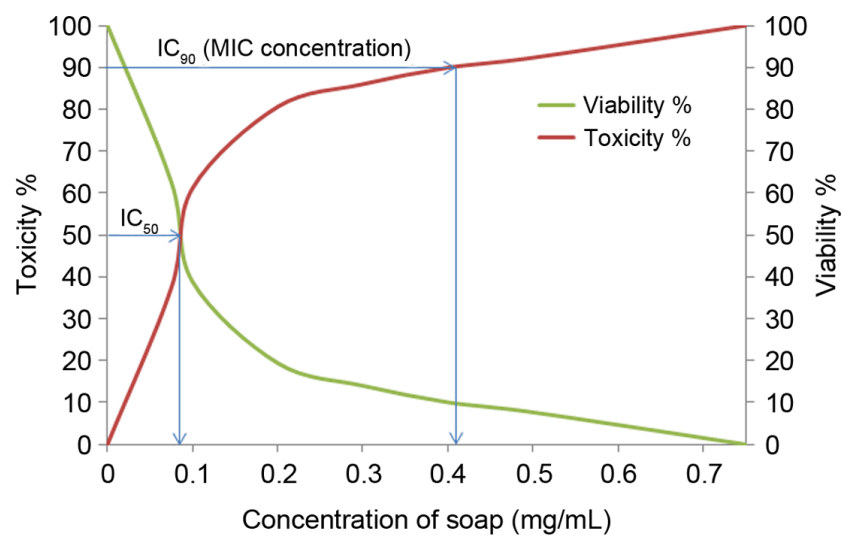

Fig. 3. Toxicity of different concentrations of soap solution and viability of the S. aureus SA812

The resulting absorbance for samples with added soap and controls and the percentage of inhibition in each measured point is presented in Table 1 and Table 2.

Table 1. Absorbance for the sample with added soap made from fresh oil and control, and inhibition percentage during the first 7 hours of experiment

\begin{tabular}{cccc}
\hline \multirow{2}{*}{ Time $(\mathrm{h})$} & \multicolumn{3}{c}{ Absorbance } \\
\cline { 2 - 4 } & Culture with added soap & Control & Inhibition () \\
\hline 0 & 0.0457 & 0.0457 & 0 \\
1 & 0.1237 & 0.0767 & 0 \\
2 & 0.1517 & 0.1327 & 0 \\
3 & 0.1627 & 0.1690 & 3.7 \\
4 & 0.1693 & 0.1887 & 10.2 \\
5 & 0.1717 & 0.2190 & 21.6 \\
6 & 0.1747 & 0.2530 & 31.0 \\
7 & 0.1833 & 0.2907 & 36.9 \\
\hline
\end{tabular}

ISSN 1996-4536 (print) • ISSN 2311-0783 (on-line) • Біологічні Студії / Studia Biologica • 2020 • Том 14/№1 • C. 23-32 
Table 2. Absorbance for the sample with added soap made from fried oil and control, and inhibition percentage during the first 7 hours of experiment

\begin{tabular}{cccc}
\hline \multirow{2}{*}{ Time (h) } & \multicolumn{3}{c}{ Absorbance } \\
\cline { 2 - 4 } & Culture with added soap & Control & Inhibition (\%) \\
\hline 0 & 0.0457 & 0.0457 & 0 \\
1 & 0.1510 & 0.0767 & 0 \\
2 & 0.1680 & 0.1327 & 0 \\
3 & 0.1683 & 0.1690 & 0.4 \\
4 & 0.1687 & 0.1887 & 10.6 \\
6 & 0.1663 & 0.2190 & 24.0 \\
7 & 0.1640 & 0.2530 & 35.2 \\
\hline
\end{tabular}

Figure $4 B$ and Fig. 5B shows the trends of growth for the sample with added soap and control. From slope coefficient we can read percentage of inhibition for soap sample against the control.

A

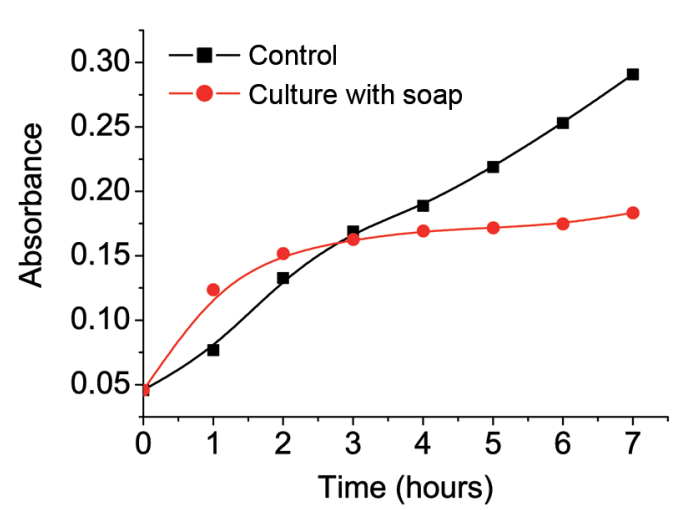

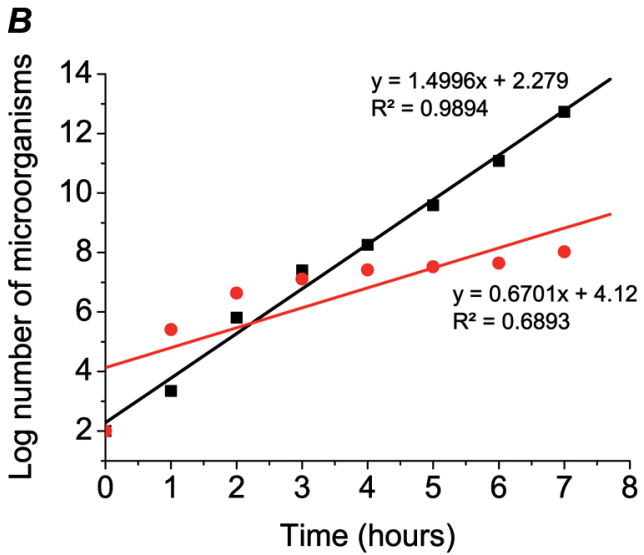

Fig. 4. Comparative graphs for growth of controls and culture with added soap made from fresh oil, $\boldsymbol{A}$ : absorbance change over time, $\boldsymbol{B}$ : logarithmic number of microorganisms change over time

The concentrations of $0.3 \mathrm{mg} / \mathrm{mL}$ of soaps made from fresh and from fried oils were taken for the experiments on Bioscreen microbiology reader. The optical density was measured during the first 7 hours of incubation in wells. On Fig. 4A and Fig. 5A can be seen that during the first two hours the solution with added soap showed higher absorbance in comparison to the control, but during the next 5 hours, it started to show a trend with lower slope coefficient.

The constant of growth for control was 1.4996, for culture with added soap made of fresh oil 0.6701 (Fig.4B), and for culture with added soap made of fried oil 0.4544 (Fig. 5B)

ISSN 1996-4536 (print) • ISSN 2311-0783 (on-line) • Біологічні Студії / Studia Biologica • 2020 • Том 14/№1 • С. 23-32 
from which it can be calculated that overall inhibition of the growth of microorganism $S$. aureus during the first 7 hours. Inhibition was $55.3 \%$ when it was subjected to the soap made of fresh oil and $69.7 \%$ when it was subjected to the soap made of fried oil against the control. The obtained linear regression $R^{2}$ was acceptable for the growth of bacteria colonies with the addition of soap made of fresh oil and it was 0.6893 (Fig. 4B). On the other hand, growth trend line of bacteria subjected to soap made from fried oil was obtained with regression 0.3627 (Fig. $5 B$ ), which cannot be accepted as valid for accurate assessment of the results. The possible reason might be in the optical interference of some compounds which might be present in soap made of frying oil, and which could have occurred during the screening process.
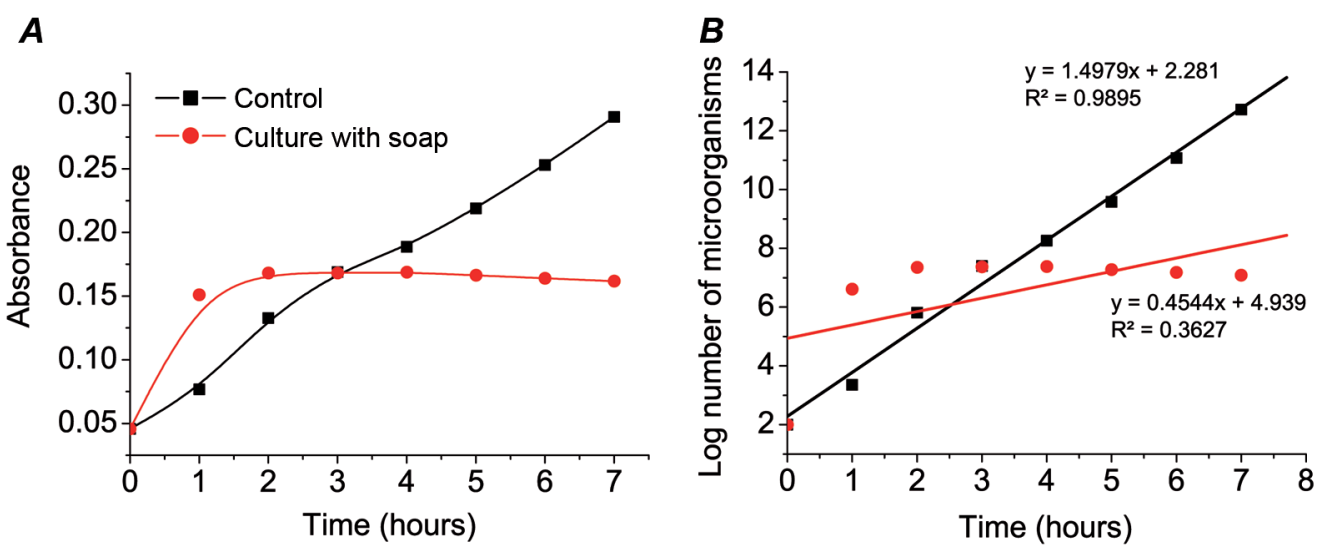

Fig. 5. Comparative graphs for growth of controls and culture with added soap made from fried oil, $\boldsymbol{A}$ : absorbance change over time, $\boldsymbol{B}$ : logarithmic number of microorganisms change over time

The two approaches were used: the agar dilution method for determining the MIC and automatic Bioscreen system for the following kinetics. The agar dilution method gave us some concrete values as a result but it required a lot of work in preparation of the single experiment. In order to compare it with other methods, it's necessary to standardize the number of microorganisms treated. It was proven that antibiotics were more potent while affect the lower number of colonies in the experiments and vice versa [11]. Thus the Bioscreen came up as a solution as it has many options with the possibility of screening of several samples in different concentrations including the controls. The obtained results are then easily and accurately comparable [22]. 24 hours of work on Bioscreen can replace more than 30 days of manual work in the laboratory, which attribute the Bioscreen as a very powerful device for in vitro microbial analysis [4].

Finding the best methodology is important for further development and supporting the production of natural soaps and their assessment. The advantage of natural soaps over commercially available ones is that they do not contain chemicals which are in a lot of cases added in order to increase the antibacterial activity. The triclosan is very often the ingredient of liquid soaps and it represents one of the biggest pharmaceutical contaminant found in river samples in the USA. Triclocarban is mostly present in bar soaps. Those chemicals can also come to the human food chain since triclosan was detected in human breast milk [2]. These findings are emphasizing the importance of constant search of natural sources for antimicrobial agents, both for nature and human population.

ISSN 1996-4536 (print) • ISSN 2311-0783 (on-line) • Біологічні Студії / Studia Biologica • 2020 • Том 14/№1 • С. 23-32 


\section{CONCLUSIONS}

The study emphasized the issues concerning the antimicrobial determination of natural produced soaps. The differences observed between soap samples produced from heat-treated and not heat treated edible plant oils are also indicating the specific characteristics of these two products. The soaps produced from heat-treated (fried) oil probably will be more present on the market, since this raw material for the soap production represents an ecological solution for the waste material, such as used oil from the food industry and restaurants. The main characteristic of soap is its antimicrobial properties and in our study, we tested these properties with two methods (traditional cultivation and Bioscreen methodology). Bioscreen methodology is less time consuming than cultivation method and also due to less human manipulation, there is a lower chance of technical mistakes. The research showed significant differences between results gained by Bioscreen methodology between soaps produced with heated and not heated oil. These results are pointing out the necessity of different sample preparation for Bioscreen. The impurities in soaps produced from used oil can be the possible reason for these observed differences. Though, this hypothesis will be tested in our ongoing and future experiments. The conducted research gained important information about antimicrobial analysis of homemade soaps, especially because this kind of experiment, by our knowledge, has not been described yet.

\section{COMPLIANCE WITH ETHICAL STANDARDS}

Conflict of Interest: The authors declare that the research was conducted in the absence of any commercial or financial relationships that could be construed as a potential conflict of interest.

Animal Rights: This article does not contain any studies with animal subjects performed by the any of the authors.

1. Abdoulaye T., Severin K. K., Bakary C., Karamoko O., Adama C. Antibacterial activity of soap containing hexane extract of leaves of Morinda morindoides (Morinda; Rubiaceae) against Staphylococcus aureus and Pseudomonas aeruginosa. Int. J. Curr. Microbiol. App. Sci, 2017; 6: 512-517.

[DOI: https://doi.org/10.20546/ijcmas.2017.601.061; Google Scholar]

2. Aiello A.E., Larson E. Antibacterial cleaning and hygiene products as an emerging risk factor for antibiotic resistance in the community. The Lancet Infectious Diseases, 2003; 3(8): 501-506.

[DOI: https://doi.org/10.1016/S1473-3099(03)00723-0; Google Scholar]

3. Aiello A.E., Larson E.L., Levy S.B. Consumer antibacterial soaps: effective or just risky? Clinical Infectious Diseases, 2007; 45(2): S137-S147.

[DOI: https://doi.org/10.1086/519255; PMid: 17683018; Google Scholar]

4. Anon, 2020: [ebook] Available at: http://www.bioscreen.fi/images/Bioscreen\%20User\%20Manual\%202015.pdf

[Accessed 30 Jan. 2020]

5. Azahar W.N.A.W., Bujang M., Jaya R.P., Hainin M.R., Mohamed A., Ngad N. Jayanti D.S. The potential of waste cooking oil as bio-asphalt for alternative binder - an overview. Jurnal Teknologi, 2016; 78(4): 111-116.

[DOI: https://doi.org/10.11113/jt.v78.8007; Google Scholar]

ISSN 1996-4536 (print) • ISSN 2311-0783 (on-line) • Біологічні Студії / Studia Biologica • 2020 • Том 14/№1 • С. 23-32 
6. Bedoux G., Roig B., Thomas O., Dupont V., Le Bot B. Occurrence and toxicity of antimicrobial triclosan and by-products in the environment. Environmental Science and Pollution Research, 2012; 19(4): 1044-1065.

[DOI: https://doi.org/10.1007/s11356-011-0632-z; PMid: 22057832; Google Scholar]

7. Brandwein M., Doron S., Shiri M. Microbial biofilms and the human skin microbiome. NPJ Biofilms and Microbiomes, 2016; 2(1): 1-6.

[DOI: https://doi.org/10.1038/s41522-016-0004-z; PMid: 28649397; Google Scholar]

8. Félix S., Araújo J., Pires A.M., Sousa A.C. Soap production: A green prospective. Waste Management, 2017; 6: 190-195.

[DOI: https://doi.org/10.1016/j.wasman.2017.04.036; PMid: 28455208; Google Scholar]

9. Griffin S.G., Markham J.L., Leach D.N. An agar dilution method for the determination of the minimum inhibitory concentration of essential oils. Journal of Essential Oil Research, 2000; 12: 249-255.

[DOI: https://doi.org/10.1080/10412905.2000.9699509; Google Scholar]

10. James J.Y., Manus M.B., Mueller O., Sarah C. Windsor, Julie E. Horvath, Charles L. Nunn. Antibacterial soap use impacts skin microbial communities in rural Madagascar. PLOS ONE, 2018; 13(8): e0199899.

[DOI: https://doi.org/10.1371/journal.pone.0199899; PMid: 30125279; PMCid: PMC6101359; Google Scholar]

11. Kolarević S., Milovanović D., Avdović M., Oalđe M., Kostić J., Sunjog K., Nikolić B., KneževićVukčević J., Vuković-Gačić B. Optimisation of the microdilution method for detection of minimum inhibitory concentration values in selected bacteria. Botanica Serbica, 2016; 40: 29-36. [Google Scholar]

12. Lambert R.J., Johnston M.D., Simons E.A. Disinfectant testing: use of the Bioscreen Microbiological Growth Analyser for laboratory biocide screening. Letters in Applied Microbiology, 1998; 26: 288-292.

[DOI: https://doi.org/10.1046/j.1472-765X.1998.00334.x; PMid: 9633095; Google Scholar]

13. Maniak B., Szmigielski M., Piekarski W. and Markowska A. Physicochemical changes of post frying sunflower oil. Int. Agrophysics, 2009; 23: 243-248.

[Google Scholar]

14. Maotsela T., Gwiranai D., Edison M. Utilization of Waste Cooking Oil and Tallow for Production of Toilet "Bath" Soap. Procedia Manufacturing, 2019; 35: 541-545.

[DOI: https://doi.org/10.1016/j.promfg.2019.07.008; Google Scholar]

15. Nikolaou I.E., Evangelinos K.I. Allan S. A reverse logistics social responsibility evaluation framework based on the triple bottom line approach. Journal of Cleaner Production, 2013; 56: 173-184.

[DOI: https://doi.org/10.1016/j.jclepro.2011.12.009; Google Scholar]

16. Obi C.N. Antibacterial Activities of Some Medicated Soaps on Selected Human Pathogens.

American Journal of Microbiological Research, 2014; 2(6): 178-181.

[DOI: https://doi.org/10.12691/ajmr-2-6-3; Google Scholar]

17. Percival S.L., Emanuel C., Cutting K.F., Williams, D.W. Microbiology of the skin and the role of biofilms in infection. International Wound Journal, 2012; 9: 14-32.

[DOI: https://doi.org/10.1111/j.1742-481X.2011.00836.x; PMid: 21973162; Google Scholar]

18. Riaz S., Adeel A., Shahida H. Antibacterial activity of soaps against daily encountered bacteria. African Journal of Biotechnology, 2009; 8(8): 1431-1436. [Google Scholar]

19. Scalise A., Bianchi A., Tartaglione C., Bolletta E., Pierangeli M., Torresetti M., Marazzi M., Di Benedetto G. Microenvironment and microbiology of skin wounds: the role of bacterial biofilms and related factors. In: Seminars in Vascular Surgery, Vol. 28, WB Saunders, 2015; No. 3-4: 151-159.

[DOI: https://doi.org/10.1053/j.semvascsurg.2016.01.003; PMid: 27113281; Google Scholar]

ISSN 1996-4536 (print) • ISSN 2311-0783 (on-line) • Біологічні Студії / Studia Biologica • 2020 • Том 14/№1 • С. 23-32 
20. Singh-Ackbarali D., Maharaj R., Mohamed N., Ramjattan-Harry V. Potential of used frying oil in paving material: solution to environmental pollution problem. Environmental Science and Pollution Research, 2017; 24: 12220-12226.

[DOI: https://doi.org/10.1007/s11356-017-8793-z; PMid: 28353106; PMCid: PMC5410207; Google Scholar]

21. Syed A.K., Ghosh S., Love N.G., Boles B.R. Triclosan promotes Staphylococcus aureus nasal colonization. MBio, 2014; 5(2): e01015-13.

[DOI: https://doi.org/10.1128/mBio.01015-13; PMid: 24713325; PMCid: PMC3993860; Google Scholar]

22. Wu Y., Griffiths M.W., McKellar R.C. A comparison of the Bioscreen method and microscopy for the determination of lag times of individual cells of Listeria monocytogenes. Letters in Applied Microbiology, 2000; 30: 468-472.

[DOI: https://doi.org/10.1046/j.1472-765x.2000.00748.x; PMid: 10849278; Google Scholar]

Received / Одержано

30 January 2020
Accepted / Прийнято

11 March 2020
Published / Опубліковано

5 May 2020

ISSN 1996-4536 (print) • ISSN 2311-0783 (on-line) • Біологічні Студії / Studia Biologica • 2020 • Том 14/№1 • С. 23-32 